\title{
INFORMATION SUPPORT OF MANAGEMENT ACTIVITY OF FORESTRY ENTERPRISES OF UKRAINE
}

\section{ІНФОРМАЦІЙНЕ ЗАБЕЗПЕЧЕННЯ УПРАВЛІНСЬКОЇ ДІЯЛЬНОСТІ ЛІСОГОСПОДАРСЬКИХ ПІДПРИЕМСТВ УКРАЇНИ}

\section{Tetiana Haiduchok ${ }^{1}$ \\ Volodymyr Mostepanyuk ${ }^{2}$}

DOI: https://doi.org/10.30525/978-9934-26-049-0-6

Abstract. The importance of this research is caused by the leading trend in development and successful commercial performance of enterprises, including forestry, that is gained by introduction of information technology. In the era of the industrial revolution, the use of information technology allows businesses to change their own business model, through the use of modern digital technologies in management. In the context of digitalization of society, information itself, as a resource, has a dominant role in management processes and technologies.

The issue on information support of management activities of forestry enterprises is vital for managers, as the correct solution of this problem allows to improve the processes of collecting, obtaining, using and storing the received information, which is the basis of information relations.

The scientific research is based on the construction of an innovative information support system for forestry enterprises management. Search and formation of the mechanism of information resources management of the enterprises is adapted to application in modern conditions of economy digitalization and is a basis of the study.

The subject of the paper is to prove the need of improving theoretical foundations of information support of management activities of forestry enterprises of Ukraine.

\footnotetext{
${ }^{1} \mathrm{PhD}$ in Economics, Associate Professor,

Polissia National University, Ukraine

${ }^{2} \mathrm{PhD}$ in Economics, Associate Professor,

Polissia National University, Ukraine
} 
The main purpose of the research is to clarify the essence of the concept of «information support», «information», «information economy», to determine the main principles of information resources of forest enterprises and to form a model of their management.

To perform the study, authors used the following methods of cognition: the axiomatic method, comparison, observation, measurement, monitoring and formalization, defining the essence of the terms «information support» etc.

The national economy development proves that the forestry complex is «an economically feasible system of enterprises whose activities are conditioned by the use of forest resources, which develop due to the achievement of competitive advantages and geographical concentration on the terms of public-private partnership».

It is proved that in the management system of a forestry enterprise the effective use of information resources on the basis of modern information technologies ensures the strengthening of competitive advantages of the business entity.

Until recently, management was seen as a creative, intuitive process based on the experience, trust, knowledge and other qualities of management staff, relevant managers. Under the pressure of information technology, the management principles are modified. It is becoming necessary to change the style and methods of enterprise management, review relationships and improve communication with consumers of services.

The introduction of information systems in forestry is an urgent need, the solution of which will reduce the cost of production, assure the ability to control all stages of production, and in general, improve enterprise management.

The authors focused on and demonstrated that information support, based on the widespread use of new information technologies, computer and communication equipment, allows to increase the efficiency of forestry enterprises, optimize the use of resources, reduce paperwork through the transition to electronic management technologies.

\section{1. Ветуп}

Провідною тенденцією розвитку та успішного ведення бізнесу підприємств, в т.ч. і лісогосподарських, є впровадження інформаційних технологій. В епоху індустріальної революції використання інфор- 
маційних технологій дає можливість суб'єктам господарювання змінювати власну бізнес-модель, завдяки використанню в управлінській діяльності сучасних цифрових технологій.

В умовах цифровізації суспільства, власне інформації, як ресурсу, належить домінуюча роль в управлінських процесах і технологіях.

Ефективне функціонування лісогосподарських підприємств в сучасних умовах і потребує суттєвого підвищення рівня інформаційного забезпечення. Денисенко М. П., Колос I. В. [1, с. 20] зазначають, що «інформаційне забезпечення управління підприємством передбачає організацію цілеспрямованих масивів інформації та інформаційних потоків, яка включає збирання, зберігання, опрацювання і передавання інформації з метою аналізу одержаних результатів для підготовки, обгрунтування і прийняття управлінських рішень». Загалом, ключовим завданням менеджменту підприємства $є$ формування високоефективної системи інформаційного забезпечення управлінської діяльності, необхідної для прийняття стратегічних управлінських рішень.

Проблема інформаційного забезпечення управлінської діяльності лісогосподарських підприємств має першочергове значення для управлінців підприємства, оскільки вирішення означеної проблеми дає змогу вдосконалити процеси одержання, прийняття, використання та зберігання одержаної інформації, яка служить основою інформаційних відносин.

В основі наукового дослідження лежить побудова системи інноваційного інформаційного забезпечення управлінської діяльності лісогосподарських підприємств. Пошук та формування механізму управління інформаційними ресурсами підприємств адаптовано до застосування в сучасних умовах діджиталізації та цифровізації економіки і є основою дослідження.

\section{2. Стан лісової галузі та її місце в національній економіці України}

Розвиток національної економіки достеменно доводить, що лісогосподарський комплекс - це «економічна доцільна система підприємств, діяльність яких зумовлена використанням лісових ресурсів, що розвиваються завдяки досягненню конкурентних переваг і географічної концентрації на умовах державно-приватного партнерства» [2]. 
У вітчизняній економіці лісогосподарський комплекс займає ключову позицію в розвитку регіонів та формує на світових ринках експортний потенціал країни. Землі лісогосподарського призначення в Україні займають близько 18,0 \% (10,63 млн. га) із загальної території країни 60,3 млн. га. Проте територія України в порівнянні країнами Свропи характеризується невисоким показником лісистості $(16,7 \%)$.

За даними Агентства лісових ресурсів України «лісистість України становить $15,9 \%$ і займас 9-те місце у Свропі за площею лісів та 6-те місце за запасами деревини. Умови для лісовирощування в Україні неоднорідні, тому ліси поширені територією держави нерівномірно» [3].

Фінансово-господарська діяльність лісового господарства, як відомо, складається з лісогосподарських підприємств і спрямована на ведення лісового та мисливського господарства.

Загальна чисельність суб'єктів господарювання, які здійснюють діяльність за КВЕД 02 «Лісове господарство та лісозаготівлі» в Україні представлено на рис. 1.

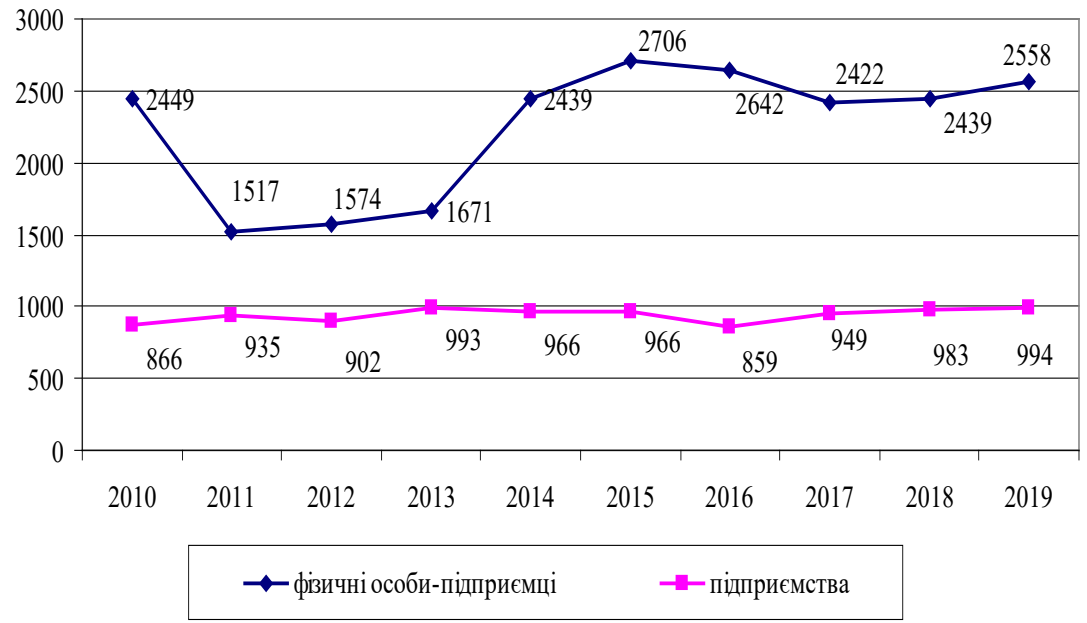

Рис. 1. Динаміка чисельності суб' сктів господарювання за КВЕД 02 «Лісове господарство та лісозаготівлі»

Джерело: узагальнено авторами за даними http://www.ukrstat.gov.ua/ 
В нинішніх умовах в лісовому господарстві та лісозаготівлі господарює біля 4,0 тис. суб'єктів господарювання, 3 яких майже 1,0 тис. підприємств і більше 2,5 тис. ФОПів. За даними рис. 1, кількість лісогосподарських підприємств зросла з 866 у 2010 році до 994 - у 2019 р.

Як відомо, переважна кількість продукції лісу виробляється та надається лісогосподарськими підприємствами, що входять до Державного агентства лісових ресурсів України. Показники, що характеризують господарську діяльність зазначених підприємств представлено в табл. 1.

Таблиця 1

Показники діяльності державних лісогосподарських підприсмств за 2017-2019 pр. та I півріччя 2020 року

\begin{tabular}{|l|c|c|c|c|}
\hline \multicolumn{1}{|c|}{ Показники } & $\mathbf{2 0 1 7}$ p. & $\mathbf{2 0 1 8}$ p. & $\mathbf{2 0 1 9}$ р. & $\begin{array}{c}\text { I півріччя } \\
\mathbf{2 0 2 0} \text { року }\end{array}$ \\
\hline $\begin{array}{l}\text { Кількість суб'єктів господарювання, } \\
\text { що належать до сфери управління, } \\
\text { всього, з них: }\end{array}$ & 349 & 348 & 344 & 341 \\
\hline - працюючі & 318 & 317 & 310 & 308 \\
\hline - прибуткові - з числа працюючих & 297 & 302 & 300 & 276 \\
\hline - непрацюючі & 31 & 21 & 24 & 23 \\
\hline - інформація відсутня & 0 & 10 & 10 & 10 \\
\hline $\begin{array}{l}\text { Середньооблікова кількість штатних } \\
\text { працівників, осіб }\end{array}$ & 47632 & 47342 & 45354 & 42110 \\
\hline Середньомісячна заробітна плата, гривень & 8673 & 10990,1 & 10557,9 & 9723,4 \\
\hline Чистий прибуток (збиток), млн. гривень & 496,3 & 475,6 & 286,0 & 47,5 \\
\hline Загальна вартість активів, млн. гривень & 4547,6 & 5041,5 & 5267,2 & 5178,6 \\
\hline Дебіторська заборгованість, млн. гривень & 258,0 & 403,0 & 641,8 & 639,1 \\
\hline Кредиторська заборгованість, млн. гривень & 1555,0 & 1862,3 & 2167,9 & 2059,2 \\
\hline
\end{tabular}

Джерело: узагальнено авторами за даними https://www.me.gov.ua/

Результати господарської діяльності підприємств показали, що досліджуваними підприємствами отримано у 2019 році 286 млн. грн. чистого прибутку, що на 210,3 млн. грн. менше.

Наведені дані у табл. 1 свідчать також, що дебіторська заборгованість за перше півріччя 2020 року становила 639,1 млн. грн. і зросла порівняно з 2017 року на 381,1 млн. грн., або в 1,5 рази. Кредиторська 
заборгованість по Державному агентстві лісових ресурсів України станом 30.06.2020рокустановила2059,2млн.грн.ізрослазадосліджуванийперіодна 504,2 млн.грн., або 32,4 \%. В 2020 році в державному секторі лісового господарства відбулося зменшення вартості активів, кількості працівників та їх середньомісячних доходів у порівнянні з минулими роками.

У 2019 році на ведення лісового господарства було спрямовано 6,6 млрд. грн., з яких 6,4 млрд. грн. - власні кошти.

Однак ефективність діяльності підприємств дещо знизилася, про що свідчить показник рентабельності: з 2,8\% в 2018 р. до 1,9\% в 2019 р. Найвищий рівень рентабельності мають підприємства Вінницького (4,5\%), Черкаського (4,2\%), Сумського (2,9\%), Хмельницького $(2,7 \%)$ і Закарпатського $(2,6 \%)$ регіонів. На жаль, 132 підприємства мають рентабельність меншу ніж 1\%. Серед них 33 підприємства південно-східного регіону, 13 - Житомирського, 12 - Волинського, 10 - Чернігівського та 9 - Рівненського обласних управлінь лісового та мисливського господарства.

В умовах сьогодення лісогосподарський комплекс України є важливою складовою економіки держави. Водночас, в Україні, особливої актуальності набуває проблема неконтрольованої вирубки лісів і експорту української деревини.

Аналізуючи основні показники, згідно даних Державної служби статистики, використання та відтворення лісів України за 2017-2019 рр. можна відмітити, що спостерігається позитивна динаміка зменшення площі рубок, водночас, площа відтворення також зменшується. Показник відтворення у зіставленні із показником рубки лісів майже у 9 р. менший (рис. 2).

Навесні 2020 року лісогосподарськими підприємствами, які входять до сфери управління Держлісагентства, проведено відтворення лісів на площі - 32306 га, в тому числі шляхом відновлення лісів на площі - 30870 га, та шляхом лісорозведення або створення нових лісів на площі - 1436 га [5].

Відповідно до Публічного звіту [6] в табл. 2 здійснено контент-аналіз сплати до бюджетів податків та платежів державними підприємствами Держлісагенства за 2018-2019 рр.

Проаналізувавши дані таблиціможна зробити висновок, що за 2019 рік підприємствами лісової галузі сплачено до бюджету 4,9 млрд. грн податків, зборів та обов'язкових платежів, що на 0,1 млрд грн більше, ніж ана- 
Tetiana Haiduchok, Volodymyr Mostepanyuk

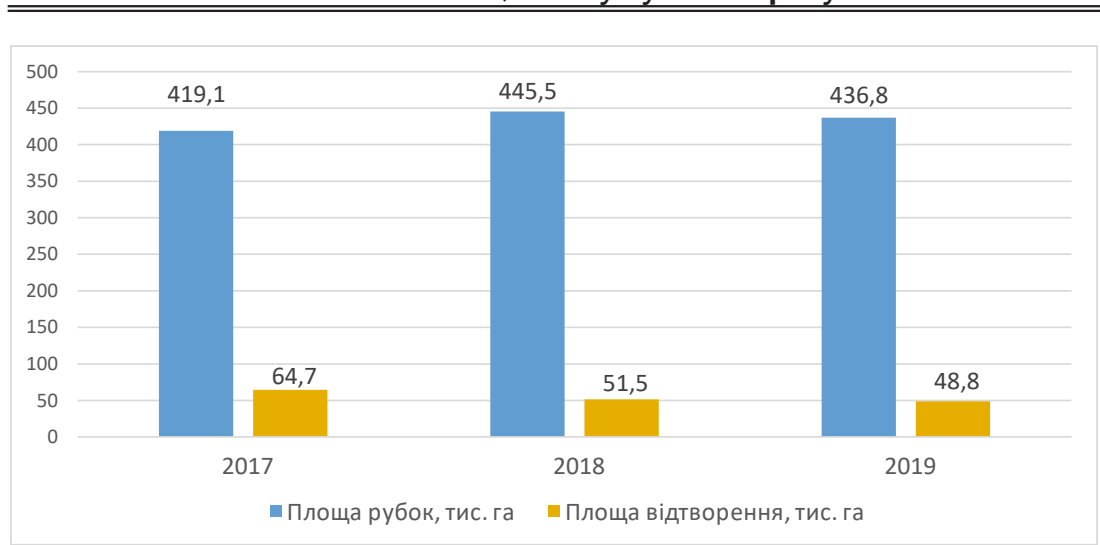

Рис. 2. Порівняння площі всіх видів рубок та заходів до лісовідтворення України за 2017-2019 рр.

Джерело: розроблено авторами за джерелом [4]

логічний показник за 2018 рік. Водночас, з них до Державного бюджету сплачено 3,0 млдр. грн, а до місцевого - 1,9 млдр грн. Найбільшу частку в сумі сплачених податків та зборів займає податок на додану

Таблиця 2

Аналіз сплати податків та платежів державними лісогосподарськими підприємствами України за 2018-2019 рр. (млрд. грн)

\begin{tabular}{|l|c|c|c|}
\hline \multirow{2}{*}{ Платежі } & \multicolumn{2}{|c|}{ Роки } & \multirow{2}{*}{ Відхилення } \\
\cline { 2 - 3 } & $\mathbf{2 0 1 8}$ & $\mathbf{2 0 1 9}$ & 0,1 \\
\hline Внесено до бюджету всього (млн грн.) & 4,8 & 4,9 & $-0,1$ \\
\hline до державного бюджету (млн грн.) & 3,1 & 3,0 & 0,1 \\
\hline $\begin{array}{l}\text { 3 них рента плата за спеціальне } \\
\text { використання лісових ресурсів (млн грн.) }\end{array}$ & 0,5 & 0,6 & 0,2 \\
\hline до місцевих бюджетів: & 1,7 & 1,9 & 0,2 \\
\hline $\begin{array}{l}\text { 3 них рента плата за спеціальне } \\
\text { використання лісових ресурсів (млн грн.) }\end{array}$ & 0,5 & 0,7 & $-0,1$ \\
\hline $\begin{array}{l}\text { Сплачено єдиного соціального внеску (ССВ) } \\
\text { (млн грн.) }\end{array}$ & 1,4 & 1,3 & 0 \\
\hline Разом сплачено податків та ЄСВ (млн грн.) & 6,2 & 6,2 & 0 \\
\hline
\end{tabular}

Джерело: розроблено авторами за [6] 
вартість - 1,9 млдр. грн, рентна плата за спеціальне використання лісових ресурсів - 1,3 млдр. грн та податок на доходи фізичних осіб 1,1 млдр. грн. Крім податків, підприємствами лісової галузі за 2019 рік сплачено 1,3 млрд. грн єдиного соціального внеску. Отже, в підсумку варто відмітити, що у 2019 році підприємствами лісової галузі разом сплачено податків та ССВ - 6,2 млрд. грн. [6].

«За даними міжнародної некомерційної неурядової організації «Лісова опікунська рада» (Forest Stewardship Council, FSC) в Україні за станом на початок 2020 року сертифіковано 4,36 мільйони гектарів лісів» [3].

Важливими показниками функціонування і розвитку лісової сертифікації за системою FSC є площа сертифікованих лісів і кількість власників сертифікатів в Україні та у всьому світі.

Станом на 01.11.2020 p. 4,55 млн. га лісів в Україні сертифіковано та видано 133 сертифікати $\mathrm{FM} / \mathrm{CoC}$ та $384 \mathrm{CoC}$. У світі відповідно 221,7 млн. га лісів сертифіковано у 82 країнах і видано 44,7 тис. сертифікатів СоC [7].

Підприємствами лісової галузі за 2019 рік заготовлено 15,6 млн м ${ }^{3}$ деревини усіх видів рубок, що в порівняні з 2018 роком на 947 тис. м або на 5,7\%, менше. Це пояснюється низьким попитом на деревину на внутрішньому ринку.

Загальний обсяг реалізованої деревини у круглому вигляді на внутрішньому ринку у 2019 році становить 13 млн м³ (загальна вартість 11,7 млрд. грн), що порівняно з 2018 роком менше відповідно на 1,3 млн м 3 та 1,5 млрд. грн.

Впродовж 2019 року лісова галузь перейшла на національні стандарти щодо визначення розмірно-якісних характеристик і класифікації лісо-та пиломатеріалів. «Перехід до нової стандартизації зумовлений розвитком нових технологій переробки деревини та євроінтеграційними процесами в лісовій галузі України. Лісоматеріали круглі (ділова деревина) в Україні розподілялися на три сорти (I, II, III) і мали низку сортиментів за їх призначенням, то з 2019 року вони розподіляються на чотири класи якості (A, B, C, D), як і в європейських країнах, без обов' язкового визначення напрямку їх використання» [3].

Таким чином, лісова галузь займає чільне місце в національній економіці та домінуючу роль для сталого розвитку агропромислового комплексу, продовольчої та енергетичної безпеки країни. 


\section{3. Механізм формування інформаційних ресурсів лісогосподарських підприємств}

Організація управління лісогосподарським підприємством, неможлива без застосування інформаційних технологій, основним ресурсом яких $є$ інформація. Дослідження український вчених, без сумніву, доказують головну роль інформації в процесі управлінської діяльності. За висновками Завадського Й. С. [12], «інформація стає більш важливим ресурсом ніж матеріальні, енергетичні, трудові та фінансові ресурси». Відповідно великого значення набувають методи обробки і використання інформації, а також технічні засоби, завдяки яким і стало можливим перетворення інформації у важливий виробничий ресурс.

«Інформація - це, насамперед, не лише ресурс, і а база інформаційного простору в економічному середовища» [8]. Багатозначність терміну «інформація» в більшості випадків призводить до багаточисленних тлумачень цього поняття.

Великий енциклопедичний словник [9] зазначає, що «під інформацією розуміють відомості, передані людьми в усний, письмовий або інший спосіб». 3 динамічним розвитком суспільства, зі збільшенням потреб суспільства у різних інформаційних послугах, інформація тлумачиться як загальнонаукове поняття, що включає обмін відомостями між людьми, людиною й автоматом; обмін сигналами у тваринному й рослинному світі.

Значна частина вітчизняних науковців віддають перевагу вивченню суто економічної інформації як основної складової процесу прийняття управлінських рішень. I в цьому є сенс, адже під економічною інформацією зазвичай, «розуміють таку інформацію, яка характеризує виробничі відносини в суспільстві» [10; 11]. За ствердженням Андрійчука В. Г. [12] «економічна інформація $\epsilon$ інструментом управління і водночас належить до його елементів, iї потрібно розглядати як один iз різновидів управлінської інформації, яка забезпечує розв'язування задач організаційно-економічного управління виробництвом».

Проте глобальна інформатизація суспільства, привела до появи якісно нового виду економіки - інформаційної [13]. «Інформаційна економіка - це господарська діяльність у сфері інформаційних послуг, їх виробництва та обміну, де основними ресурсами є інформація та знання» - таке тлумачення доводить колектив авторів - Плескач В., 
Затонацька Т. [14]. Загалом, варто погодитися 3 дослідженнями Малика I. П. [15], на думку якого, «інформаційна економіка - це такий тип економіки, де продуктивність і конкурентоспроможність господарюючих суб' єктів залежать головним чином від їх здатності генерувати, обробляти й ефективно застосовувати інформацію, засновану на знаннях». Наведені тлумачення дають тільки фрагментарну картину відповідної економічної системи.

Сучасний розвиток нашої держави потребує значних обсягів дослідження механізму функціонування лісогосподарських підприємств як в розрізі оперативного управління, так і в довгостроковій перспективі. В умовах сьогодення в складі лісогосподарського підприємства прийнято виділяти декілька категорій ресурсів. Водночас, особлива увага належить інформаційним ресурсам, які є одним з важливих елементів ведення сучасного бізнесу, а процес управління ними потребує дослідження як теоретичних, так і практичних аспектів.

Економічні перетворення в державі зумовлюють необхідність як розробки нової стратегії розвитку лісового господарства, так і нових підходів до формування інформаційних ресурсів лісогосподарських підприємств.

Під методологічними основами використання інформаційних ресурсів лісогосподарських підприємств слід розуміти єдність концептуальних, теоретичних і технологічних основ забезпечення на інформаційному рівні формування, накопичення і використання інформації суб'єктом господарювання.

Інформаційне забезпечення лісогосподарських підприємств - це сукупність форм документів, нормативно-правової бази та реалізованих управлінських рішень щодо обсягу інформації, яка існує в системі автоматизованого оброблення економічної інформації.

Основні принципи інформаційних ресурсів лісогосподарських підприємств узагальнено на рис. 3 .

Акумульована інформація є основним підгрунтям для прийняття управлінських рішень в лісогосподарських підприємствах. Цінність і своєчасність прийнятих рішень значною мірою залежить від здатності суб'єкта господарювання в потрібний момент зібрати, проаналізувати та відтворити інформацію.

Особливої уваги заслуговує підхід розподілу облікової інформації на фінансову та управлінську є актуальним для лісогосподарських 
Принципи формування інформаційних ресурсів лісогосподарського підприємства

\begin{tabular}{|c|c|c|}
\hline$\rightarrow$ & $\begin{array}{c}\text { принцип } \\
\text { доцільності }\end{array}$ & $\begin{array}{l}\text { полягає у розкритті тих фактів та явищ в межах } \\
\text { господарської діяльності лісогосподарського підприємства, } \\
\text { що можуть бути корисними для управління }\end{array}$ \\
\hline & $\begin{array}{c}\text { принцип } \\
\text { достовірності }\end{array}$ & $\begin{array}{l}\text { полягає у формуванні точних та об’єктивних даних, які } \\
\text { офіційно підтверджені }\end{array}$ \\
\hline & $\begin{array}{l}\text { принцип } \\
\text { повноти }\end{array}$ & $\begin{array}{l}\text { полягає у проходженні всіх етапі формування облікової } \\
\text { інформації: від збору та узагальнення до безпосередньої } \\
\text { передачі даних }\end{array}$ \\
\hline & $\begin{array}{c}\text { принцип } \\
\text { оперативності }\end{array}$ & $\begin{array}{l}\text { полягає у дотриманні визначеного за етапами проходження } \\
\text { та часовими проміжками формування плану-графіка при } \\
\text { максимальному використанні сучасного технічного } \\
\text { оснащення та забезпеченні високого кваліфікаційного рівня } \\
\text { працівників }\end{array}$ \\
\hline & $\begin{array}{c}\text { принцип } \\
\text { правильності } \\
\text { оформлення }\end{array}$ & $\begin{array}{l}\text { полягає в тому, що інформаційні дані дотримуються вимог } \\
\text { чинного нормативного поля } 3 \text { питань господарської } \\
\text { діяльності суб’єкта, а також обліку, контролю та аналізу } \\
\text { результатів діяльності. }\end{array}$ \\
\hline & $\begin{array}{c}\text { принцип } \\
\text { безперервності }\end{array}$ & $\begin{array}{l}\text { полягає в тому, що інформаційні ресурси мають } \\
\text { безперервний характер функціонування, виходячи } 3 \\
\text { безперервної діяльності суб'єкта. }\end{array}$ \\
\hline & $\begin{array}{l}\text { принцип } \\
\text { лаконічності }\end{array}$ & $\begin{array}{l}\text { полягає в тому, інформаційні блоки викладені лаконічно, } \\
\text { компетентно, зрозуміло. }\end{array}$ \\
\hline & $\begin{array}{c}\text { принцип } \\
\text { захищеності }\end{array}$ & $\begin{array}{lccr}\text { полягає в } & \text { передбачені } & \text { надійності } & \text { збереження } \\
\text { інформаційних } & \text { даних та } & \text { забезпечення } & \text { лише } \\
\text { санкціонованого доступу до них } & & \end{array}$ \\
\hline
\end{tabular}

\section{Рис. 3. Принципи формування інформаційних ресурсів} лісогосподарського підприємства

підприємств, що в свою чергу передбачає наявність кількох категорій користувачів економічної інформації (рис. 4).

Механізмом інформаційного забезпечення обліково-аналітичної системи управління лісогосподарського підприємства є єдність систем 


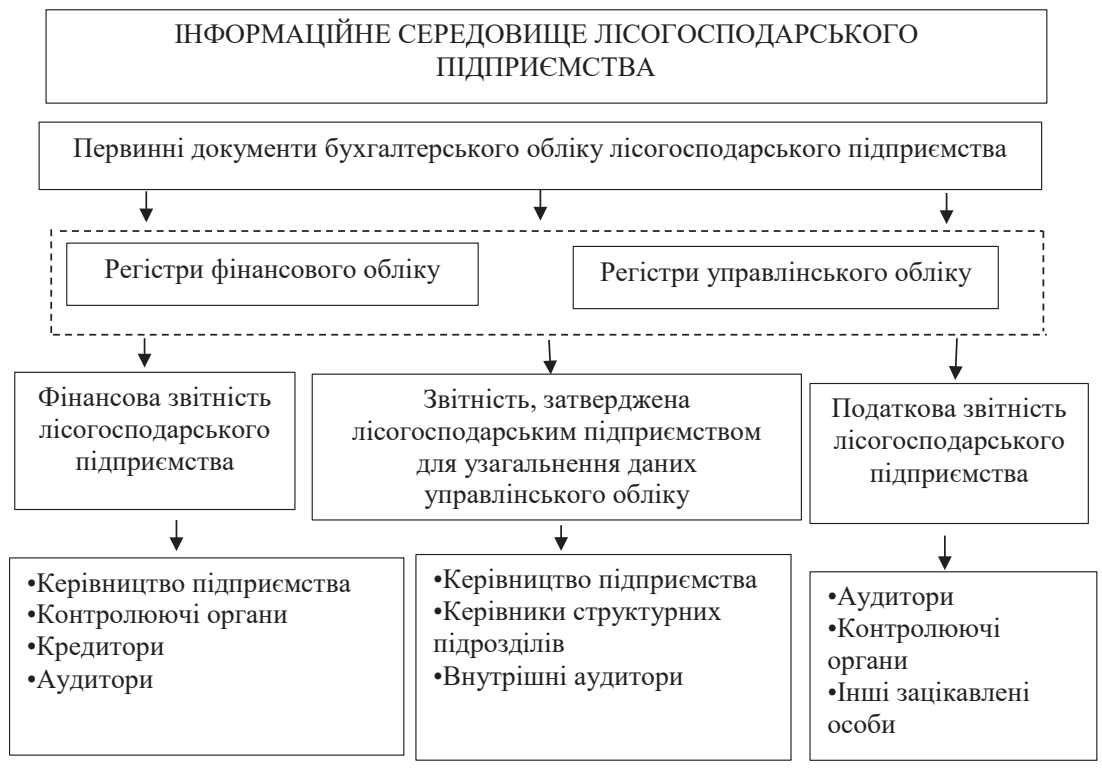

\section{Рис. 4. Розподіл потоків облікової інформації в рамках фінансового та управлінського обліку лісогосподарського підприємства}

обліку, аналізу та контролю, об’єднаних інформаційними потоками для управління економічними процесами суб'єкта господарювання.

Інформацію як сукупність відомостей про внутрішній і зовнішній стан системи управління лісогосподарського підприємства використовують для оцінки і аналізу економічних процесів 3 метою прийняття управлінських рішень. Управління діяльністю лісогосподарського підприємства - це процес пізнання сучасного стану та визначення потреб розвитку об'єкта управління на основі сформованої облікової інформації, з можливістю подальшого розвитку та прийняття оптимальних управлінських рішень.

Виходячи з вищевказаного визначимо, що в системі управління лісогосподарським підприємством ефективне використання інформаційних ресурсів на засаді сучасних інформаційних технологій забезпечує посилення конкурентних переваг суб’ єкта господарювання. 
Розглядаючи діяльність лісогосподарських підприємств, можемо виділити матеріальні, нематеріальні, природні, енергетичні, фінансові і трудові, ресурси. Але ці поняття $є$ економічними категоріями.

Наразі є розуміння того, що для нормального функціонування підприємства недостатньо мати для виробництва тільки необхідні матеріальні, людські та фінансові ресурси, - необхідно знати, що з цим усім потрібно робити, це - по-перше; i, по-друге, потрібно володіти інформацією про сучасні інноваційні технології; машини й обладнання; соціальні-правові зміни у зовнішньому середовищі. Тільки тоді інформація стане ресурсом виробництва і може розглядатися як окрема економічна категорія [16]. Тобто, інформаційні ресурси можна визначити як увесь обсяг інформації, що є в інформаційній системі.

Що ж $є$ джерелом формування інформаційних ресурсів лісогосподарських підприємства Будь-яке лісогосподарське підприємство являє собою економічну систему, в середині якої постійно існують інформаційні зв'язки між окремими елементами. Основою цих зв'язків і $\epsilon$ економічна інформація.

Залежно від джерела виникнення розрізняють внутрішню і зовнішню інформацію. Інформація внутрішнього середовища повно відображає фінансово-господарський стан підприємства і $є$ досить точною. Сукупність внутрішніх і зовнішніх інформаційних ресурсів, на нашу думку, складає єдиний інформаційний ресурс лісогосподарських підприємств. Він використовується безупинно для зв'язку та координування (управління) кожної фази перетворення матеріальних, трудових, енергетичних та фінансових ресурсів на продукцію.

Формування інформаційного ресурсу підприємства 3 точки зору кібернетичного підходу може здійснюватися таким чином (рис. 5).

Як і будь-яким ресурсом, інформаційними ресурсами можна і необхідно управляти. Хоча не існує ще досконалого оцінювання інформаційних ресурсів, а також проведення моніторингу та здійснення прогнозування потреби в них. Проте на рівні підприємства можна і треба вивчати інформаційні потреби, планувати й управляти ними. Схематично це матиме вигляд (рис. 6).

Динамічні зміни зовнішнього інформаційного середовища визначають тенденції розвитку управлінських інформаційних систем та спонукають підприємства, у т. ч. і досліджувані, перетво- 
Chapter «Economic sciences»

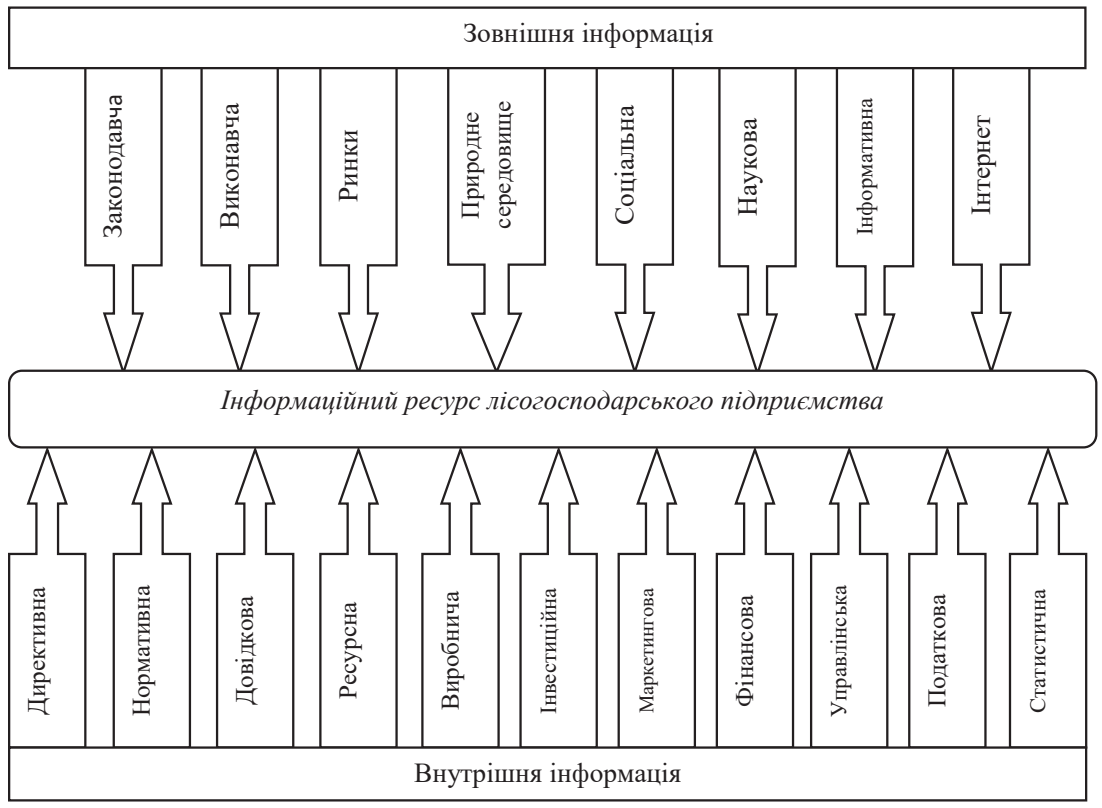

Рис. 5. Модель формування інформаційного ресурсу лісогосподарського підприємства

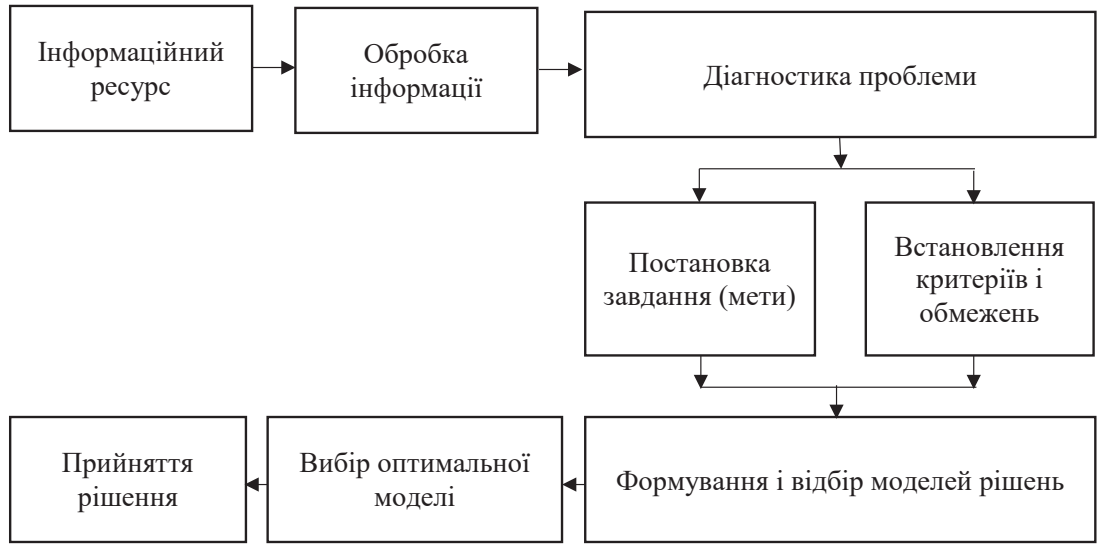

Рис. 6. Модель управління інформаційними ресурсами лісогосподарського підприємства 
рюватися на складніші системи, для яких необхідні перспективні методи управління [17].

Серед проблем, які мають негативний вплив на кінцевий результат управлінської діяльності підприємства можна визнати [18]:

- недостатнє матеріально-технічне та програмне забезпечення для створення автоматизованих систем управління інформаційними ресурсами;

- відсутність чітко сформованих комунікаційних каналів руху інформаційних ресурсів у внутрішньому середовищі підприємства для прийняття та реалізації управлінських рішень;

- недосконалий механізм розподілу інформаційних ресурсів відповідно до потреб різних рівнів управлінського персоналу, що призводить до дезорганізації цінної інформації та гальмує процес прийняття рішень.

Вирішити вказані проблеми можна шляхом впровадження в управлінську діяльність підприємств чітко сформованої інформаційної системи. Запровадження інформаційних систем забезпечує менеджменту підприємств оперативний доступ до нагромадженої інформації 3 тією метою, щоб надалі ефективно її використовувати для вирішення поставлених завдань.

\section{4. Адаптація управлінських інформаційних систем} до сучасних умов управління підприємств

До останнього часу управління розглядали як творчий, інтуїтивний процес, що базується на досвіді, довірі, знаннях та інших якостях працівників управління, відповідних менеджерів [19]. Під тиском інформаційних технологій відбувається переродження принципів управління. Необхідно змінювати стиль і методи управління підприємствами, переглядати взаємовідносини та покращувати комунікації зі споживачами послуг [20].

Лісове господарство відрізняється від інших галузей національної економіки завдяки притаманним тільки йому особливостям. До таких особливостей слід віднести, насамперед, специфіку виробництва, що пов'язана з біологічними перетвореннями сировини та природних ресурсів. Крім того, лісогосподарське виробництво є багатопрофільним, характеризується великою кількістю виробничих процесів та значною номенклатурою продукції, що випускається. 
Тому, впровадження в лісове господарство інформаційних систем нагальна потреба, вирішення якої призведе до зменшення собівартості продукції, можливості контролювання на всіх ділянках виробництва, та загалом, покращення управління підприємством.

Технологія вибору та впровадження на підприємстві управлінської інформаційної системи показано на рис. 7.

Інформаційні ресурси одержані в цій системі повинні бути направлені на прийняття управлінських рішень, одержання максимального доходу і ефективного розподілу одержаного доходу.

Стає закономірним явище, що нині для вітчизняних лісогосподарських підприємств дедалі достовірнішими й необхіднішими стають концепції інформаційних систем, такі як ERP, що широко використовуються для комп'ютеризації світової економіки.

Проблеми вибору інформаційних систем управління на підприємстві

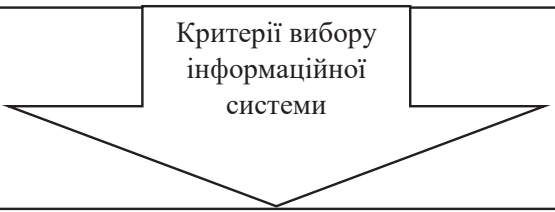

Аналіз інформаційних систем на базі вибору критеріїв

Вибір інформаційної системи управління

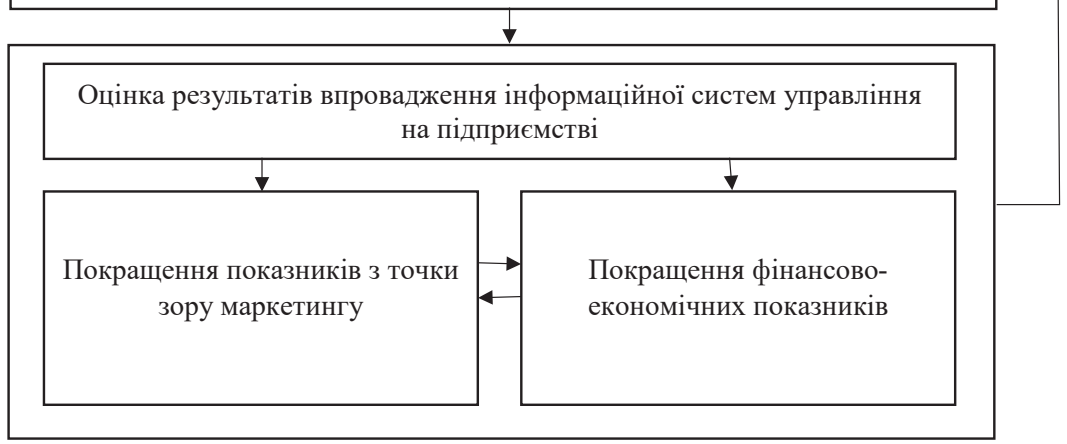

Рис. 7. Технологія вибору управлінської інформаційної системи підприємства 
ERP-система (Enter priseresource planning) - це велика система комплексної автоматизації процесу формування та прийняття оперативний та об'єктивних управлінських рішень менеджментом будь-якого підприємства. Вона включає функції планування потреб у виробничих ресурсах, технологічної підготовки виробництва, складання бюджетів фінансових ресурсів - доходів і витрат, а також контроль за їхнім виконанням [21].

Сьогодні на ринку ІТ-технологій представлені різні інформаційні системи оптимізації управлінських процесів на підприємствах. Це, насамперед, системи управління персоналом і взаємин з клієнтами (CRM); системи управління логістикою підприємства (WMS-системи); системи управління поставками (SCM); облікові системи (автоматизують облікові функції управління, зокрема з точки зору бухгалтерського обліку), а також системи стратегічного управління (ВРМ - системи бюджетного планування і контролю).

Експерти з впевненістю запевняють, що саме ці системи максимально затребувані більшістю вітчизняних підприємств.

ERP-системи, як і будь-що, мають свої переваги та недоліки. Представлені системи покликані полегшити роботу управлінців підприємств, взявши на себе вирішення поставлених завдань. Ключовими перевагами можна назвати:

Такі системи покликані допомагати персоналу підприємства, взявши на себе вирішення певних завдань, серед яких:

- підвищення ефективності управління підприємством;

- доступність даних. Один раз внесені дані стають доступні в рамках цілої системи, при цьому не потрібні звірки, додаткові узгодження і перевірки;

- забезпечення постійного обліку, контролю надходження та прозорість витрачання грошових коштів і матеріальних ресурсів;

- організація ефективного планування і прогнозування;

- контроль роботи співробітників;

- оперативний аналіз діяльності всіх центрів відповідальності підприємства;

- підвищення ефективності обміну даних між центрами відповідальності підприємств.

Недоліки таких систем є наслідком їх переваг. Єдина база даних i єдина система породжують проблеми забезпечення безпеки даних. 
Оскільки в системі працюють всі центри відповідальності і працівники підприємства, то і права доступу необхідно налаштувати для кожного свої. І якщо при використанні окремих спеціалізованих програм зазвичай потрібно створити кілька рівнів доступу, то система прав доступу в ERP виходить складною. Тут потрібно налаштувати і доступ до модулів для різних центрів, і всередині кожного центру відповідальності налаштувати ієрархію [22].

Отже, впровадження на підприємстві ERP-системи спрощує процес управління підприємством і тим самим дає можливість звільнити менеджерів від рутинної роботи. При цьому можна в перспективі очікувати підвищення ефективності діяльності підприємства та його конкурентоспроможність на ринку.

\section{5. Висновки}

Підвищення ефективності функціонування лісогосподарських підприємств, покращення інформаційного забезпечення управлінської діяльності можливе лише шляхом впровадження інформаційних інструментів управління ними. Тому, результати проведеного наукового дослідження дозволяють зробити наступні висновки:

1) економічна інформація є важливим чинником організації та управління лісогосподарським виробництвом;

2) внутрішні та зовнішні інформаційні ресурси, складаючи єдиний інформаційний ресурс підприємства, мають прямий і опосередкований вплив на виробничі процеси лісогосподарських формувань;

3) інформаційними ресурсами лісогосподарських підприємств можна і необхідно управляти, вивчивши перед цим потребу у них;

4) $є$ необхідність впровадження в систему менеджменту лісогосподарських підприємств сучасних комплексних управлінських інформаційних систем.

Отже, інформаційне забезпечення, що базується на широкому застосуванні нових інформаційних технологій, засобів комп'ютерної та комунікаційної техніки, дає змогу підвищувати ефективність роботи лісогосподарських підприємств, оптимізовувати використання ресурсів, скорочувати документообіг з переходом до електронних технологій управління. 


\section{Список літератури:}

1. Денисенко М. П., Колос І. В. Інформаційне забезпечення ефективного управління підприємством. Економіка та держава. 2006. № 7. С. 19-24.

2. Дребот О. Сутність лісового комплексу: теоретичні та методологічні аспекти. Економіст. 2011. № 10. С. 14-16.

3. Публічний звіт державного агентства лісових ресурсів України за 2019 рік. URL: https://cutt.ly/5hVmHjo

4. Державна служба статистики України: офіційний сайт. URL: http://www.ukrstat.gov.ua/

5. Лісовідновлення та лісорозведення. URL: http://dklg.kmu.gov.ua/forest/ control/uk/publish/article?art_id.

6. Публічний звіт державного агентства лісових ресурсів України за 2019 рік. URL: https://mepr.gov.ua/files/images/news_2020/26022020

7. Факти та цифри. URL: https://ua.fsc.org/ua-ua/nasha-diyalnist/facts and figures

8. Гордієнко Л. П. Документування витрат незавершеного виробництва на пивоварному підприємстві. Проблеми теорії та методології бухгалтерського обліку, контролю і аналізу. 2015. Вип. 1(31). С. 80-92.

9. Большой энциклопедический словарь. URL: http://www.vedu.ru

10. Завадський Й. С. Менеджмент: Management. Київ : Українсько-фінський інститут менеджменту і бізнесу, 1997. Т. 1.543 с.

11. Вовчак I. С. Інформаційні системи та комп'ютерні технології в менеджменті : навч. посіб. Тернопіль : Карт-бланш, 2001. 354 с.

12. Андрійчук В. Г. Економіка аграрних підприємств : підруч. 2-ге вид., доп. і перер. Київ : КНЕУ, 2002. 624 с.

13. Гончар М. С. Математичні основи інформаційної економіки : монографія. Київ : Інститут теоретичної фізики, 2007. 464 с.

14. Плескач В. Л., Затонацька Т. Г. Електронна комерція : підручник. Київ : Знання, 2007. 535 с.

15. Малик І. П. Тенденції розвитку інформаційної економіки в Україні. Вісник Східноєвропейського університету економіки і менеджменту. 2013. Вип. 1(14). 2013. С. 25-34

16. Івахненков С. В. Інформаційні технології в організації бухгалтерського обліку та аудиту : навч. посіб. Київ : Знання-Прес, 2003. 349 с.

17. Ванькович Л. Я. Характеристика окремих типів управлінських інформаційних систем. Вісн. наи. ун-ту «Львівська політехніка». Менеджмент та підприємництво в Украӥні: етапи становлення і проблеми розвитку. 2008. № 624. С. 19-23.

18. Химиця Н., Сорохтей М. Інформаційне забезпечення управлінської діяльності підприємства. Інформачія, комунікаиія, суспільство 2013 : матеріали 2-ої Міжнар. наук. конф. ІКС-2013, 16-19 трав. 2013 року, Україна, Львів, Славське. Львів : Видавництво Львівської політехніки, 2013. С. 218-219.

19. Бланк I. О. Фінансовий менеджмент : навч. посіб. Київ : Ельга, 2008. 724 с.

20. Володимиренко В. М. Створення ефективного інструменту управління лісовим господарством. Науковий вісник Наиіонального університету біоресурсів і природокористування України. Сер. : Лісівнищтво та декоративне садівництво. 2015. Вип. 229. С. 20-26. 
21. Коваль С. В. Удосконалення комп'ютерного обліку у сільськогосподарських підприємствах. Вісн. Бердянського ун-ту менеджменту $і$ бізнесу. 2012. № 3(19). C. 161-163.

22. Дэниел О’Лири. ERP-системы: выбор, внедрение, эксплуатация. Современное планирование и управление ресурсами предприятия. Москва : Вершина, 2004. 356 с.

\section{References:}

1. Denysenko M. P., Kolos I. V. (2006) Informatsiine zabezpechennia efektyvnoho upravlinnia pidpryiemstvom [Information support of effective enterprise management]. Ekonomika ta derzhava, no. 7, pp. 19-24.

2. Drebot O. (2011) Sutnist lisovoho kompleksu teoretychni ta metodolohichni aspekty [The essence of the forest complex: theoretical and methodological aspects]. Ekonomist, no. 10, pp. 14-16.

3. Publichnyi zvit derzhavnoho ahentstva lisovykh resursiv Ukrainy za 2019 rik [Public report of the state agency of forest resources of Ukraine for 2019]. Retrieved from: https://cutt.ly/5hVmHjo

4. Derzhavna sluzhba statystyky Ukrainy ofitsiinyi sait [State Statistics Service of Ukraine: official site]. Retrieved from: http://www.ukrstat.gov.ua/

5. Lisovidnovlennia ta lisorozvedennia [Reforestation and afforestation]. Retrieved from: http://dklg.kmu.gov.ua/forest/control/uk/publish/article?art_id

6. Publichnyi zvit derzhavnoho ahentstva lisovykh resursiv Ukrainy za 2019 rik [Public report of the state agency of forest resources of Ukraine for 2019]. Retrieved from: https://mepr.gov.ua/files/images/news_2020/26022020

7. Fakty ta tsyfry [Facts and figures]. Retrieved from: https://ua.fsc.org/ua-ua/ nasha-diyalnist/facts_and_figures

8. Hordiienko L. P. (2015) Dokumentuvannia vytrat nezavershenoho vyrobnytstva na pyvovarnomu pidpryiemstvi [Documenting the costs of work in progress at the brewery]. Problemy teorii ta metodolohii bukhhalterskoho obliku kontroliu $i$ analizu, vol. 1(31), pp. 80-92.

9. Bolshoy entsiklopedicheskiy slovar [Big encyclopedic dictionary]. Retrieved from: http://www.vedu.ru

10. Zavadskyi Y. S. (1997) Menedzhment: Management [Management: Management]. Kyiv: Ukrainsko-finskyi instytut menedzhmentu i biznesu. (in Ukrainian)

11. Vovchak I. S. (2001) Informatsiini systemy ta kompiuterni tekhnolohii $v$ menedzhmenti [Information systems and computer technologies in management]. Ternopil: Kart-blansh. (in Ukrainian)

12. Andriichuk V. H. (2002) Ekonomika ahrarnykh pidpryiemstv [Economics of agricultural enterprises]. Kyiv: KNEU. (in Ukrainian)

13. Honchar M. S. (2007) Matematychni Osnovy Informatsiinoi Ekonomiky [Mathematical foundations of information economy]. Kyiv: Instytut Teoretychnoi Fizyky. (in Ukrainian)

14. Pleskach V. L. Zatonatska T. H. (2007) Elektronna komertsiia [E-commerce]. Kyiv: Znannia. (in Ukrainian) 
15. Malyk I. P. (2013) Tendentsii rozvytku informatsiinoi ekonomiky v Ukraini [Trends in the development of the information economy in Ukraine]. Visnyk skhidnoievropeiskoho universytetu ekonomiky i menedzhmentu, vol. 1(14), pp. 25-34.

16. Ivakhnenkov S. V. (2003) Informatsiini tekhnolohii v orhanizatsii bukhhalterskoho obliku ta audytu [Information technologies in the organization of accounting and auditing]. Kyiv: Znannia-Pres. (in Ukrainian)

17. Vankovych L. Ya. (2008) Kharakterystyka okremykh typiv upravlinskykh informatsiinykh system [Characteristics of certain types of management information systems]. Visn. nats. un-tu «Lvivska politekhnika». Menedzhment ta pidpryiemnytstvo v Ukraini: etapy stanovlennia i problemy rozvytku, no. 624, pp. 19-23.

18. Khymytsia N., Sorokhtei M. (2013) Informatsiine zabezpechennia upravlinskoi diialnosti pidpryiemstva [Information support of management activities of the enterprise]. Proceedings of the Informatsiia, komunikatsiia, suspilstvo 2013 (Ukraina, Lviv, Traven 16-19, 2013), Lviv: Vydavnytstvo Lvivskoi politekhniky, pp. $218-219$.

19. Blank I. O. (2008) Finansovyi menedzhment [Financial management]. Kyiv: Elha. (in Ukrainian)

20. Volodymyrenko V. M. (2015) Stvorennia efektyvnoho instrumentu upravlinnia lisovym hospodarstvom [Creating an effective forest management tool]. Naukovyi visnyk Natsionalnoho universytetu bioresursiv i pryrodokorystuvannia Ukrainy. Ser: Lisivnytstvo ta dekoratyvne sadivnytstvo, vol. 229, pp. 20-26.

21. Koval S. V. (2012) Udoskonalennia kompiuternoho obliku u silskohospodarskykh pidpryiemstvakh [Improvement of computer accounting in agricultural enterprises]. Visn. Berdianskoho un-tu menedzhmentu i biznesu, no. 3. pp. 161-163.

22. Deniel O'Liri (2004) ERP-sistemyi: vyibor, vnedrenie, ekspluatatsiya. Sovremennoe planirovanie i upravlenie resursami predpriyatiya [ERP-systems: selection, implementation, operation. Modern planning and enterprise resource management]. Moscow. (in Russian) 